\title{
Literatura jako challenge? Media społecznościowe na tapecie - nauczyciele i uczniowie przy tablicy i... tablecie
}

\author{
Literature as a "Challenge"? \\ Social Media on the Calendar - Teachers and Students \\ at the Blackboard and ... on Tablet
}

Summary: The review is an overview of the dissertation by Agnieszka Kulig-Kozłowska, $\mathrm{Fa}$ cebook on a school bench. Social media versus Polish language education, which deals with social media in modern Polish education. The publication is an interesting proposition from the point of view of didactic practice. The author has grounded her paper on a vast and diverse empirical material and a solid theoretical foundation, which makes it possible that the teacher whose knowledge of the subject of social media is not thorough will treat the book as a social media guide, whereas the proficient Polish language teachers who easily find their way through the media labyrinth will creatively adapt the innovative projects of the author to the needs of their own classes. Thus, the reviewer invites a potential reader to enter into a creative dialogue with the proposals included in the work by the Cracow didactic.

Key words: social media, Facebook, student, identity, hero, new media reading

Wyjście z domu bez smartfona jest dla 30-latka jak wyjście bez ręki.

Dla 20-latka jest jak wyjście bez głowy, a dla gimnazjalisty jest jak wyjście bez siebie.

1 J. Podgórska: Tubylcy z tysięcy subświatów - wywiad z Tomaszem Szlendakiem. „Ja, My, Oni — Poradnik Psychologiczny Polityki” 2014, z. 16, s. 6. 
Jako polonista nie mam najmniejszych wątpliwości, że książkę Agnieszki Kulig-Kozłowskiej powinien przeczytać każdy odpowiedzialnie praktykujący swoje szlachetne rzemiosło (powołanie, misję) nauczyciel języka polskiego. Powodów jest co najmniej kilka.

Po pierwsze, póki co, mimo obserwowanego w antroposferze swoistego kultu Facebooka, a co za tym idzie równoległego bycia i życia „na fejsie”, gdzie dominuje autoprezentacja i mozaikowa tożsamość „globalnych nastolatków” i ich nauczycieli „zamkniętych w cyfrowych komorach” (s. 94), wciąż brak jest na rynku wydawniczym publikacji próbujących całościowo zmierzyć się z zagadnieniem wykorzystania mediów społecznościowych jako efektywnego narzędzia edukacyjnego w dydaktyce polonistycznej. Po wtóre rozwój technologii medialnych oraz związana z nim dynamika terminologii i tworzonych in statu nascendi teorii sprawia, że tylko najodważniejsi badacze i praktycy wchodzą na grząski grunt eksploracji pogranicza logo- i mediosfery, próbując ująć w ramy opisu fragmenty „stającej się” rzeczywistości „nowomedialnej”. W ponowoczesnej szkole ze względu na antropologiczny charakter kształcenia polonistycznego jest to zagadnienie kluczowe, jednak w związku z wpisanym weń instytucjonalnym konserwatyzmem zarazem najtrudniejsze.

Nie jest bowiem fraszką łączenie innowacyjnej motywacji do „skamieniałej” lektury z ostentacyjnym nieczytaniem, kreatywności ze ściąganiem z sieci, Wokulskiego z portalem aukcyjnym, języka elipsy (emotki, hasztagu, hejtu, i lajku) z etyką i etykietą słowa. Nie jest igraszką poruszanie przez nauczycieli zakamarków uczniowskiego ducha światami idei czy literackie podróże w czasie i przestrzeni, kiedy na ekranie smartfona tu i teraz „staje się już” z każdym nowo dodanym wpisem na Facebooku czy Instagramie. Wcale również nie jest „lajtowe”, jak mawia młodzież, przekonanie nastawionych najczęściej co najmniej sceptycznie (o ile nie z lękiem) nauczycieli, że media społecznościowe nie gryzą i pod pewnymi warunkami (podstawowa orientacja w zasadach ich funkcjonowania oraz znajomość tzw. lektury nowomedialnej) są w szkole jak najbardziej funkcjonalne, że tkwi w nich potencjał, który można wykorzystać. Kulig-Kozłowskiej to karkołomne przedsięwzięcie (czy mówiąc bardziej nowomedialnie: challenge), które/y przed sobą postawiła, udaje się w pełni zrealizować, więc tym bardziej zasługuje ono na uznanie. Kluczem do sukcesu autorki jest

zachowanie równowagi między mediami łaknącymi uwagi i czasu a wymagającym skupienia tekstem (s. 226).

Cała książka hołduje tej wyrażonej expressis verbis dopiero w zakończeniu publikacji zasadzie złotego środka i pewnie dlatego trafia do mnie jako nauczy-

${ }^{2}$ A. Kulig-Kozłowska: Facebook w szkolnej ławce. Media społecznościowe a edukacja polonistyczna. Kraków 2017, s. 252. 
ciela, który co jakiś czas obserwuje fazy zachłystywania się różnorodnymi nowinkami i spory między ewolucjonistami i rewolucjonistami w dydaktyce. Siła książki tkwi właśnie w umiejętnym łączeniu przez krakowską badaczkę tradycji i przyszłości.

Nie będę omawiał szczegółowo kompozycji rozprawy — robi to sama autorka we wstępie, dokonując przeglądu zawartości, unikalnych inspiracji i ukształtowania materiału teoretycznego oraz empirycznego (Kulig-Kozłowska uczestniczyła m.in. w projektach IBE i MNiSW), będącego podstawą poszczególnych rozdziałów. Istotniejszym jest podkreślenie w tym miejscu wielowymiarowości, złożoności, płynności i dziewiczości zagadnienia mediów społecznościowych w szkole, co skutkuje w tekście interferencją pól zainteresowań różnych dziedzin humanistyki: socjologii, kulturoznawstwa, medioznawstwa, psychologii czy pedagogiki. Co trzeba jednak zaakcentować, zawsze dominuje perspektywa dydaktyczna i na plan pierwszy wybija się głos cenionych dydaktyków polonistów, m.in. Stanisława Bortnowskiego, Witolda Bobińskiego, Anny Janus-Sitarz, Małgorzaty Latoch-Zielińskiej, Iwony Morawskiej, Urszuli Żydek-Bednarczuk. Gdybym miał w duchu nowych (twitterowo-esemesowych) sposobów komunikacji ująć syntetycznie ideę pracy, byłaby to cytowana przez autorkę za Stanisławem Dylakiem formuła: „o mediach, przez media, do mediów”3.

W centrum zainteresowania autorki rozprawy znajdują się tzw. media społecznościowe (ang. social media), których symbolem-ikoną jest tytułowy Facebook. To on traktowany jako narzędzie przenosi nas w inne wymiary edukacyjne o dużym potencjale, a rozpatrywany jako ikona wciąga czytelników głębiej w skomplikowaną strukturę, na którą składają się różnorodne aktywności w sieci, za pomocą mediów (nie tylko) społecznościowych. Wokół tak zarysowanego centrum wzdłuż osi wertykalnej i horyzontalnej przecinają się interesujące badaczkę dwa typy relacji: (1) nauczyciel—uczeń; (2) teoria—praktyka. Nad całością unosi się duch „,nowomedialnego” doświadczania literatury, w którym swe źródło mają wszelkie aktywności komunikacyjne uczniów na zajęciach.

W rozdziale pierwszym pracy krakowska badaczka uzasadnia odpowiednimi zapisami najnowszych dokumentów programowych konieczność integracji treści polonistycznych i medialnych, co znamienne, przywołując nie tylko zapisy podstawy programowej przedmiotu język polski, lecz także o wiele bardziej „treściwe” (m.in. o ujęcie komunikacyjne) zapisy dotyczące nauki języka obcego nowożytnego. Przy tej okazji dostrzega, że nowoczesne środki przekazu informacji pokazywane są w podstawie programowej przede wszystkim w kategoriach zagrożenia dla młodego człowieka. Ponadto uważny czytelnik

${ }^{3}$ Zob. S. Dylak: Edukacja medialna w szkole. O mediach, przez media, dla mediów. W: Media a edukacja: Kompetencje medialne społeczeństwa wiedzy. Red. W. Strykow ski, W. Skrzydlewski. Poznań 1997, s. 468. 
dokumentów zwróci uwagę na brak wyraźnie sformułowanych uwag na temat dobrych praktyk w zakresie używania nowych technologii informacyjno-komunikacyjnych i ich twórczych możliwości w pracy z tekstem literackim. Na szczęście Kulig-Kozłowska z dobrym skutkiem stara się tę lukę przynajmniej po części uzupełnić swoją pracą.

Rozdział drugi - teoretyczny — to próba definicji, zarys historii oraz syntetyczny „leksykon” mediów społecznościowych, choć najciekawszą jego część stanowi, moim zdaniem, fragment syntezujący badania postaw polonistów wobec mediów społecznościowych. Podoba mi się szczególnie charakterystyka innowacyjnego polonisty (s. 38) i skonfrontowana z nią analiza danych jakościowych zebranych podczas badań. Co z nich wynika? Po pierwsze rzuca się w oczy rozdźwięk między świadomością, postulatami i lekcyjną rzeczywistością, mieszanka ostrożnego optymizmu i postrzegania Internetu jako zagrożenia dla relacji, samodzielności myślenia, czytelnictwa; raczej pomocniczo-wspomagająca funkcja multimediów, służąca przeważnie tworzeniu sytuacji kontekstowych. Widać również swoiste „białe plamy” w „,nowomedialnych” kompetencjach nauczycielskich, na szczęście niereprezentatywne dla próby badawczej. Kulig-Kozłowska nie poprzestaje tylko na stwierdzeniu faktów, lecz definiuje trafnie przyczyny „unikowo-lękowego” stylu użytkowania nowych mediów przez nauczycieli (m.in lęk przed utratą autorytetu i zbytnim skróceniem dystansu, mieszanie prywatności i publiczności, lęk przed wykorzystaniem możliwości Internetu przeciw nauczycielowi), które nazwać można by formułą: „,szkolna proza życia”. W przeprowadzonych badaniach widoczne jest również duże zapotrzebowanie nauczycieli na wiedzę na temat social mediów, co pośrednio potwierdza niska ocena przydatności mediów społecznościowych w obszarze dydaktyki literatury i języka polskiego wystawiona przez badanych pedagogów.

W dalszej części rozdziału drugiego perspektywa nauczycielska zastąpiona zostaje omówieniem różnorodnych wymiarów dydaktycznego potencjału mediów społecznościowych w kształceniu hybrydowym (mieszanym), czyli połączeniu e-nauczania z kształceniem tradycyjnym. Swoją drogą w tym miejscu książki odczuwam pewien dysonans — odnoszę mianowicie wrażenie, że na chwilę zmienia się zaprogramowany w książce potencjalny odbiorca tekstu miejsce (prawie) kompletnego laika zajmuje nauczyciel posiadający już pewną wiedzę na temat social mediów, by po chwili, poprzez prezentację tabelki omawiającej w przystępny sposób architekturę Facebooka, powrócił ten pierwszy. Wśród różnych funkcji portali społecznościowych na czoło wybija się szeroko pojęta funkcja komunikacyjna (również w klasycznie rozumianym aspekcie kształceniowo-językowym — w końcu każdy post jest w jakimś gatunku lub jest hybrydą gatunkową) i swobodny przepływ informacji, do którego osobiście podszedłbym, znając realia szkoły i ryzyko wystąpienia informacji zniekształconej, z większą ostrożnością (co potwierdzają wyniki badań cytowane 
na s. 74-75). Pozytywnego wymiaru nabiera również asynchroniczny tryb nauki, będący szansą dla nieśmiałych, dając czas do rozwagi i namysłu, umożliwiając nawiązanie bliższej relacji. W końcowej części omawianego rozdziału krakowska badaczka próbuje wskazać przepis na zaistnienie efektywnej komunikacji w przestrzeni wirtualnej między uczniem i nauczycielem: oprócz innych pomysłów, może to być np. „,profil profesjonalny” lub grupa zamknięta.

Z kolei bohaterem rozdziału trzeciego jest ,współczesny nastolatek wieloekranowy”, „globalny nastolatek”, którego na zewnątrz charakteryzuje posiadanie obowiązkowych akcesoriów multimedialnych, a wnętrze kształtowane jest przez popkulturę i konsumpcję. Inne cechy szczególne to: wysoki stopień tolerancji, niechęć do głębszego uczestnictwa, legitymowanie się zmienną tożsamością (mozaikowość, efemeryczność, modyfikowalność tożsamości), która jest czymś na wzór autokreacji ściśle związanej z autoprezentacją również w ramach partycypacji w społecznościach internetowych. W skrajnych wypadkach liczba tożsamości młodych ludzi jest wprost proporcjonalna do liczby portali, na których są zalogowani, a największe nasilenie zjawiska zaobserwować można na dawnym III etapie edukacyjnym, również w formie tożsamości rozproszonej.

Kulig-Kozłowska zauważa, że nastolatkowie dostrzegają zagrożenia czające się w sieci, co nie zmienia faktu, że często traktują życie w sieci jako równoległe do życia realnego albo autoprezentację ulepszonego siebie w wersji 2.0. Jednocześnie $\mathrm{w}$ eksperymentach $\mathrm{z}$ tożsamością kryje się szansa na eksperyment lektury z wykorzystaniem social mediów. Jakie są doświadczenia młodych ludzi z mediami, pokazują wyniki analizy ankiety wypełnionej przez niemal stu gimnazjalistów. Co ciekawe, tylko kilkunastu spośród badanych wymieniło uczestnictwo w portalach społecznościowych wśród ulubionych form spędzania wolnego czasu, co nie zmienia faktu, że aplikacje takie jak Facebook i YouTube cieszą się wśród młodzieży największym powodzeniem (w przeciwieństwie do Twittera!), a funkcję „,centrum multimedialnego dowodzenia” sprawuje bezapelacyjnie smartfon. Internet, według deklaracji nastolatków, służy głównie do poszukiwania potrzebnych informacji i oglądania filmów, a w dalszej kolejności do kontaktów w ramach portali społecznościowych. Gimnazjalista hipotetycznie odłączony od Internetu dodatkowo zyskany czas przeznaczyłby... bynajmniej nie na czytanie książek — badanie pokazuje, że to „ostateczna ostateczność". Zarazem widać wyraźnie, że próg szkoły jest postrzegany przez uczniów jako granica, za którą media społecznościowe nie mają już wstępu, co nie zmienia faktu, że portale społecznościowe i gry byłyby w opinii badanych interesującym problemem do omówienia „na idealnej lekcji z wykorzystaniem Internetu” zamiast treści stricte polonistycznych (s. 97).

Istotną wartość dodaną pracy stanowią zakorzenione w praktyce dydaktycznej autorki konkretne przykłady wykorzystania potencjału edukacyjnego mediów społecznościowych na języku polskim (w rozdziałach czwartym i piątym). Wspomniana wcześniej cecha współczesnych nastolatków związana z tenden- 
cją do eksperymentowania z różnymi tożsamościami i dostępnymi sieciowymi środkami wyrazu, pozwala autorce postawić hipotezę, że portale społecznościowe mogą z powodzeniem zostać wykorzystane na lekcjach literackich m.in. dzięki tzw. dramie online, czyli wcielaniu się przez uczniów w bohaterów literackich czy autorów dzieła w sieci. Przykłady prezentowane przez Kulig-Kozłowską potwierdzają skuteczność tej nowatorskiej na gruncie edukacji polonistycznej metody (zaistniała dopiero w roku 2013!) jako aktywnego sposobu poznawania lektury w cyfrowym świecie przy wykorzystaniu trzech portali: Twittera, Facebooka i Edmodo. Autorka w charakterze wskazówki dla nauczycieli zamieszcza metodyczny klucz do dramy online - schemat/plan pracy metodą online na portalu społecznościowym (s. 124-126).

Inną interesującą propozycją jest wykorzystanie emotikonów do ćwiczenia umiejętności streszczania-interpretacji tekstu. Nie mniej ciekawie wyglądają propozycje przenoszenia rozwiązań cyfrowych mediów społecznościowych $\mathrm{w}$ analogową przestrzeń klasy poprzez specjalnie przygotowane karty pracy. Nie wymagały one zakładania kont na żadnym z portali i korzystania na lekcji z multimediów. Efektem działań są nowatorskie przykłady wykorzystania różnorodnych mediów i aplikacji podczas pracy z lekturą. Co warte podkreślenia, wszystkie działania, podobnie jak przy okazji dramy online, nazwałbym ,postaciocentrycznymi”. Uczeń musi coś wygooglować w sieci w związku z wyimaginowaną prośbą bohatera, sprzedać na portalu aukcyjnym przedmiot należący do postaci (odpowiednio go reklamując i opisując), wysłać SMS w imieniu bohatera, uzupełnić jego listę kontaktów w telefonie w oparciu o realia lektury, przeprowadzić w parach konwersację na „fejsie” w imieniu postaci („drama offline"), czy bazując na metodzie przekładu intersemiotycznego, narysować scenę z lektury (opisać sytuację) i opatrzyć ją odpowiednimi słowami kluczami, czyli hasztagami niczym na Instagramie. Opisane eksperymenty metodyczne unowocześniły bez wątpienia moje spojrzenie na pracę z lekturą szkolną. I to właśnie postrzegana „postaciocentrycznie” lektura „,nowomedialna” wychodzi na plan pierwszy w ostatniej części pracy — wspomnianym już rozdziale piątym.

Autorka rozpoczyna go próbą zdefiniowania lektury „nowomedialnej” (intermedialnej). To taka literatura, w której nowe media odgrywają istotną rolę konstytutywną w świecie przedstawionym lub kompozycji utworu, ale nie są jedynie popkulturową egzotyką czy nowoczesną inkrustacją, lecz istotną częścią opowiadanej historii jako temat, atrybut bohatera (rozumiany jako cecha i przedmiot), schemat fabularny czy zasada kształtująca narrację. Co istotne, literatura ta jest obarczona ryzykiem krótkiej przydatności, czyli szybkiej dezaktualizacji związanej z rozwojem technologii. To teksty, w których duże znaczenie odgrywają elementy wizualne i które cechuje hybrydyczność obrazu i tekstu, linearności i symultaniczności; gdzie zatarciu ulegają granice między dziełem a obiektami widzianymi na ekranie. Tym samym 
literatura dla młodzieży staje się multimodalną propozycją do samodzielnego „złożenia” z zestawu tekstowo-graficznych sekwencji (s. 157),

którą cechuje w wymiarze genologicznym niepowtarzalna hybrydowość. W tym kontekście (nasycenia medium głównego - literatury - mediami pobocznymi, czyli nowymi mediami) konieczna jest redefinicja polonistyki szkolnej w stronę jej bardziej interdyscyplinarnego i komparatystycznego (spod znaku komparatystyki kulturowej) charakteru (Bobiński).

Nowe media mogą stać się szansą na ocalenie lektury i tekstu w szkole w ogóle. Tym samym znajomość rozmaitych tendencji w najnowszych tekstach dla dzieci i młodzieży to nie tyko przywilej, ale i obowiązek szkolnego polonisty, który mając świadomość celu swoich działań, może wykorzystać podwójną optykę - interpretując teksty literackie, odwoływać się do swoistości nowych mediów dla dobra literatury. Niestety prawie połowa respondentów w przytaczanych przez Kulig-Kozłowską badaniach nie zna żadnych lektur nowomedialnych, a ci, którzy wykorzystują je na lekcji, czynią to przede wszystkim w sposób utylitarny, czyli jako narzędzie wychowawcze pokazujące ciemną stronę mediów. Tymczasem, jak zauważa autorka, utożsamianie się z bohaterami tekstów nowomedialnych skutkuje wzrostem motywacji do czytania i przybliża lekcje do codziennych doświadczeń uczniów. Niestety najnowsza podstawa programowa nie zmienia średniego wieku lektury, który bezustannie oscyluje wokół siedemdziesiątki (s. 167). Badaczka wśród przeszkód we wprowadzaniu nowości literackich wymienia: brak czasu, obligacje wynikające z zapisów podstawy programowej, nieznajomość rynku wydawniczego, lęk przed utratą autorytetu. Ja dodałbym ze swej strony bardziej prozaiczne, jak kondycja finansowa organu prowadzącego przekładająca się na budżet szkoły i biblioteki szkolnej... Punktem wyjścia z bezpiecznych okopów może być dla uczących zestawienie propozycji lektur nowomedialnych przeznaczonych dla wszystkich etapów edukacyjnych opracowane przez autorkę, która następnie dokonuje „postaciocentrycznego" przeglądu tekstów nowomedialnych ze względu na nowoczesny atrybut bohatera (smartfon, komputer, sieć społecznościową), by zamknąć pracę różnorodnymi propozycjami dydaktycznymi działań z tekstami nowomedialnymi.

Walory książki Kulig-Kozłowskiej to oryginalny, pionierski temat rozprawy, przejrzysty, nieutrudniający odbioru język, nastawienie na empirię, praktykę, konkret, brak zbędnego przeteoretyzowania. Wątpliwości i pytania, rodzące się podczas lektury, dotyczą możliwości realizacji niektórych projektów w rutynowym, nielaboratoryjnym trybie pracy w szkole, konieczności rozległości wybranych przypisów i ewentualności zastosowania w pewnych przypadkach prostych wizualizacji w postaci wykresów przy omawianiu procentowych wyników badań. 
Jeśli, jak można wyczytać w recenzowanej książce,

członkowie pokoleń cyfrowych mają raczej wrodzoną zwinność medialną niż medialną mądrość (s. 153),

to praca Kulig-Kozłowskiej będzie w zdobywaniu owej mądrości zarówno uczniom, jak i nauczycielom bez wątpienia niezmiernie pomocna.

\section{Bibliografia}

Dylak S.: Edukacja medialna w szkole. O mediach, przez media, dla mediów. W: Media a edukacja: Kompetencje medialne społeczeństwa wiedzy. Red. W. Strykowski, W. Skrzydlewski. Poznań 1997.

Kulig-Kozłowska A.: Facebook w szkolnej ławce. Media społecznościowe a edukacja polonistyczna. Kraków 2017.

Podgórska J.: Tubylcy z tysięcy subświatów - wywiad z Tomaszem Szlendakiem. „Ja, My, Oni Poradnik Psychologiczny Polityki” 2014, z. 16. 